\title{
運転者から見た分離帯高木植栽の景観イメージの評価
}

\section{Landscape Evaluation of Planting High Trees in Separators from Drivers' Point of View}

亀野 辰三* 熊野 稔** 岩立 忠夫*** 松井万里子*

Tatsumi KAMENO Minoru KUMANO Tadao IWATATE Mariko MATSUI

\begin{abstract}
摘要 : 本研究は,運転者から見た分離帯高木植栽の景観評価について言及したものである。まず，広 幅員の駅前通りを想定し、CG を用いて樹形之樹高幅員比 (H／D)を操作した分離帯高木植栽の景観 評価モデルを作成した。次に，景観評価実験を行い，因子分析と重回帰分析により，被験者の評価構 造を分析した。これらの分析結果から，1）街路景観の評価は「好ましさ」感に強く影響されること が示され，2）望ましいH/Dは, 円錐型と球形型の樹形では $0.3(\mathrm{H}=9.0 \mathrm{~m})$, 盃状型では $0.2(\mathrm{H}=$ $6.0 \mathrm{~m})$, 卵円型は $0.2 \sim 0.3(H=6.0 \sim 9.0 \mathrm{~m})$ であることが判明した。つまり, 分離帯高木植栽におけ る景観面での望ましい樹高は，総幅員の 2 割〜 3 割程度の值と考えられる。
\end{abstract}

\section{1.はじめに}

「道路緑化技術基準・同解説」1”による,都市を代表する道 路における緑化に求められる主要な機能は「景観向上および緑陰 形成となり, 都市又は地域の個性を強く表現することが求められ ている。と述べられているように, 緑化による道路の個性化が 諨われている。本研究で対象とした駅前通りも都市を代表する道 路になる可能性が高い街路であり, そこでの街路樹は街路の演出 要素として，より個性化を図る必要があると考えられる。

本研究は, 駅前通り等の広幅員街路における景観向上之個性化 を図るために, 分離帯に高木を植栽した際の景観イメージを定量 的に把握することを目的としたものである。ところで, 分離帯高 木植栽を対象としてその景観評価を扱った既往の研究は, 歩道植 樹帯高木植栽のそれと比べ，これまであまり見ることができない。 後者を扱った研究には，例えば，フォトモンタージュ法を用いて 街路修景・緑化モデルを構築した下村 ${ }^{2)} ら の$ 研究や, 街路樹が運 転者之歩行者双方に及ぼす影響について考察した市橋 ${ }^{3}$ らの研究, また，建物高さと街路樹高さとの関係を分析し，それらが高くな るにつれて街路景観の総合評価が低くなることを明らかにした山 滝 ‘) ら研究等, これまで多くの蓄積が見られる。しかしながら, 今後のみちづくりにシンボル性や個性化を求める潮流に応えるた めには，分離帯に高木植栽を行った場合の景観評価を実証的に分 析しておく必要があると考えられる。

これまで, わが国では土地の制約等を主因として街路樹は歩道 植栽が一般的であった。しかしながら, 分離帯高木植栽は歩道植 栽に比べると，いくつかのメリットがあることも事実である。そ れらを列挙すると，1）緑視率の向上，2）緑に井まれる心地よさ， 3）夜間運転時における防眩効果，4）踏压による樹木の生長の障 害防止，5）落ち葉による苦情の発生の低減，6）信号機や標識類 の視認性の向上，7）民有地への枝の侵入防止，8）歩道を根が持 ち上げることによる舗装の破壊防止，等が考えられる.5.

一方, 分離帯高木植栽は, 交差点では植栽による対向車等が見 えにくくなり死角が生じ易く, また, 歩道植栽と分離帯植栽で樹 種の選定をどうするか，あるいは樹高のバランスをどう図るか等 も課題として挙げられよう。また, 道路の正面に山や城などのシ ンボルを持って来てビス夕を形成する場合に，分離帯高木植栽は 景観疎外要素になる抢それがある。このように幾つかの解決す心゙ き課題もあるが, 本研究では, これまで街路の景観設計への取り
組みが遅れてきた分離帯への高木植栽の導入を促進させるために, まずは景観イメージの定量的評価を試みたものである。

ここで, 本研究の流れを述べると, 本研究では 4 車線街路にお ける分離帯高木植栽を研究対象にしている。そこで，まず，全国 の駅前に位置する 4 車線広幅員街路（幅員 $30 \mathrm{~m}$ 以上）のうち, 分離帯に高木植栽を施している街路を調査してその実態を把握す る。次に，その結果を踏まえ，景観評価のための景観擬似画像を コンピュータ・グラフィックス（以下， CGという）を用いて作 成し, 評定尺度法による評価実験を行う。そして, その集計結果 から, 因子分析, 重回帰分析を行い, 樹形別・樹高幅員比別に総 合評価との関係を考察する。

\section{2. わが国における分離帯高木植栽の現状}

亀野 ${ }^{5.7)}$ らは，わが国におけるシンボルロードの現状を把握する ために, 1994 年の秋に全国 686 の地方自治体を対象に，「都市を 代表する街路と街路樹に関する全国地方自治体調查」（以下，全 国自治体調查という）を実施した。本調査では，各自治体に自ら の都市を代表する街路（以下，シンボルロードという）を一路線 選んでいただき，その路線名や横断構成，場所等を記入していた だいた。また, その道路に植栽されている街路樹について, 樹種 名や植栽形式, 維持管理の方法, 街路景観の評価等を何った（表一 1)。アンケートの回収率は $85.4 \%$ （回収数 $=586$ 都市）を示し た。

この調査より, 本研究で対象とした駅前に位置する 4 車線道路 で分離帯高木植栽をしている事例は，表一 2 に示す 15 都市であ ることが明らかになった。同表からは，植栽されている樹種では ケヤキ, クスノキ, サクラ, イチョウ等が多く採用されているこ とが分かる。また，幅員別では，最大の総幅員を有する道路は東 京都文京区にある都市計画道路の $40 \mathrm{~m}$ であるが， $30 \mathrm{~m}$ が標準的

\begin{tabular}{c|c} 
表 -1 & 全国自治体調査の調查項目 \\
\hline 項目名 & \multicolumn{1}{|c}{ 調 查 内 容 } \\
\hline 質問 $\mathrm{A}$ & 都市を代表する街路について \\
質問 B & 質問Aに植裁されている街路樹について \\
質問 C & 街路樹の維持管理について \\
質問 D & 街路樹の評価について \\
質問 E & 街路樹をめぐる問題点·話題等 \\
\hline
\end{tabular}

*国立大分工業高等専門学校土木工学科 **国立徳山工業高等専門学校土木建築工学科 ${ }^{* * *}$ 国土交通省関東地方整備局 
表一 2 わが国における分離帯高木植栽を有する代表的街路 (4 車線)

\begin{tabular}{|c|c|c|c|c|c|}
\hline No & 路 線 名 & 都市名 & $\begin{array}{c}\text { 総幅员 } \\
(\mathrm{m})\end{array}$ & \begin{tabular}{|l|l|} 
分離带 \\
幅員 $(\mathrm{m})$ \\
\end{tabular} & 植载椹種 \\
\hline 1 & 新幹線停車場線 & 燕市 & 33.0 & 3.0 & ケヤキ \\
\hline 2 & 大垣駅前線 & 大垣市 & 36.0 & 2.5 & $\begin{array}{l}\text { ケヤキ・クスノキ・ヤマモ } \\
\text { モ・モッコク }\end{array}$ \\
\hline 3 & 大宮下横町線 & 飯田市 & 30.0 & 8.0 & リンゴ・サクラ \\
\hline 4 & 青莱通り線 & 静岡市 & 36.0 & 18.0 & ケヤキ・シラカシ \\
\hline 5 & 港橋横砂線 & 清水市 & 30.0 & 2.4 & アラカシ \\
\hline 6 & 三橋中央通線 & 大宮市 & 30.0 & 2.0 & $\begin{array}{l}\text { クスノキ・エンジュ・八ナミ } \\
\text { ズキ }\end{array}$ \\
\hline 7 & 市道3-853号線 & 所沢市 & 36.0 & 2.0 & ケヤキ \\
\hline 8 & 昭和通り線 & $\begin{array}{l}\text { ひたち } \\
\text { なか市 }\end{array}$ & 32.0 & 7. 0 & $\begin{array}{l}\text { イョゥウ・ナッツバキ・バナ } \\
\text { ミズキ・ナナカマド・ツツジ }\end{array}$ \\
\hline 9 & 第1淖頭西舞駅線 & 舞鶴市 & 35.0 & 3.4 & ケヤキ \\
\hline 10 & $\begin{array}{l}\text { 東京都都市計画道 } \\
\text { 路 }\end{array}$ & 文京区 & 40.0 & 10.0 & サクラ \\
\hline 11 & 君津駅前線 & 君津市 & 36.0 & 4.0 & $\begin{array}{l}\text { トウカエデ・ケヤキ・アメリ } \\
\text { カディゴ }\end{array}$ \\
\hline 12 & 中央循環線 & 松山市 & 30.0 & 5.0 & イチョウ・トベラ \\
\hline 13 & 斉田嶋門駅線 & 鳴門市 & 30.0 & 2.0 & クスノキ・サクラ \\
\hline 14 & 八町通前田町30号 & 豊橋市 & 30.0 & 5.5 & クスノキ・ブラタナス \\
\hline 15 & 犬山駅東線 & 犬山市 & 30.0 & 2.0 & ケヤキ \\
\hline
\end{tabular}

な総幅員となっている。分離带の幅員をみると, 最大分離帯幅が 静岡市にある都市計画道路 (青葉通り線) の $18 \mathrm{~m}$ で, 最も多い 分離帯の幅は $2 \mathrm{~m}$, 平均幅員は約 $5 \mathrm{~m}$ であった。

\section{3. 景観擬似画像の作成}

\section{(1) CG の作成条件}

本研究では, 駅前に位置する分離帯を有する 4 車線道路を想定 している。そこで，影観擬似画像を作成するに当たり，以下のよ うな仮定を設定した。

まず, 道路の横断構成では, 現行道路構造令並びに, 前述した 全国自治体調查結果を踏まえ, 総幅員は $30.0 \mathrm{~m}$ とし, 步道 $4.0 \mathrm{~m}$ $\times 2$, 分離帯 $5.0 \mathrm{~m}$, 車道部幅員 $8.5 \mathrm{~m}$ （車道 $3.25 \mathrm{~m} \times 2+$ 路側 帯 $2.00 \mathrm{~m} ） \times 2$ とした。また, 分離帯には同一樹種で一列植栽 の街路樹を $10 \mathrm{~m}$ 間隔で配した。なお, 沿道には都心部の駅前通 りを想定し，かつ，画像のスケール感を明確に表すために，20〜 $30 \mathrm{~m}$ の中高層建築物を配置した。採用した樹形に関しても亀野 ${ }^{8}$ らの研究を踏まえ, 代表的な樹形である盃状形, 円錐形, 卵円形, 球形型の 4 種類とし, それぞれの樹形ごとに, 樹高幅員比 (H/ D)を 0.1 から 0.5 までの 5 段階を設定した（表一 3 )。つまり， 樹高を $3 \mathrm{~m}$ ピッチで 5 段階変化させた画像を作ることになる。

(2) CG の作成方法

CGは「my Shade」（Expression Tools 社）を使用して作 成した。まず, 路面デー夕を作成する。その後, 歩車道部や境界 ブロック等の描画を行い，建築物や樹木を加工して加える。今回 は樹木以外のデー夕は共通であるため, 樹木を除いたべース CG をまず作成し，次に樹木を看板方式で配置した。レンダリングは 最も簡易な計算手法であるスキャンラインを使用して行う。以上 の方法により作成した画像数は全部で 4 樹形 $\times 5$ 樹高幅員比 $=20$ 画像であるが，紙面の都合によりその一例を図一 1 に示す。なお，
視点場は自動車の運転手を想定し, 車道端から内側寄り $1.0 \mathrm{~m}$, 高さを $1.2 \mathrm{~m}$ に設定した。

\section{4. 景観評価実験と結果}

\section{（1）実験方法}

本研究では液晶プロジェクター（SONY VPL-V5000QJ）を 使用してパソコン画面を直接スクリーン上に投影した。投影順序 はランダムに, 合計 20 枚の擬似画像を一画像（画質：幅 $640 \times$ 縦 480(ピクセル), 色数 : 16bit High Color) ずつ 90 秒間提示 した。プロジェクターとスクリーンの距離と水平画角は，それぞ れ $3.1 \mathrm{~m}, 40^{\circ}$ である。被験者は国立大分高専土木工学科の教職 員 10 名之学生（4・5 年生） 55 名, 合計 65 名（男性 47 名, 女 性 18 名）であるが,実験室の定員の関係で 2 回に分けて実験を行っ た（1回目：31名，2 回目：34名）。心理量の測定には評定尺度 法を用い，一画像毎に表一 3 に示す 15 の評価項目の形容詞対に 対して，それぞれ 俳常に〜やや〜普通〜やや〜非常に\} の 5 段 階の評定尺度で，また総合評価として，\{大变好き〜好き〜普通

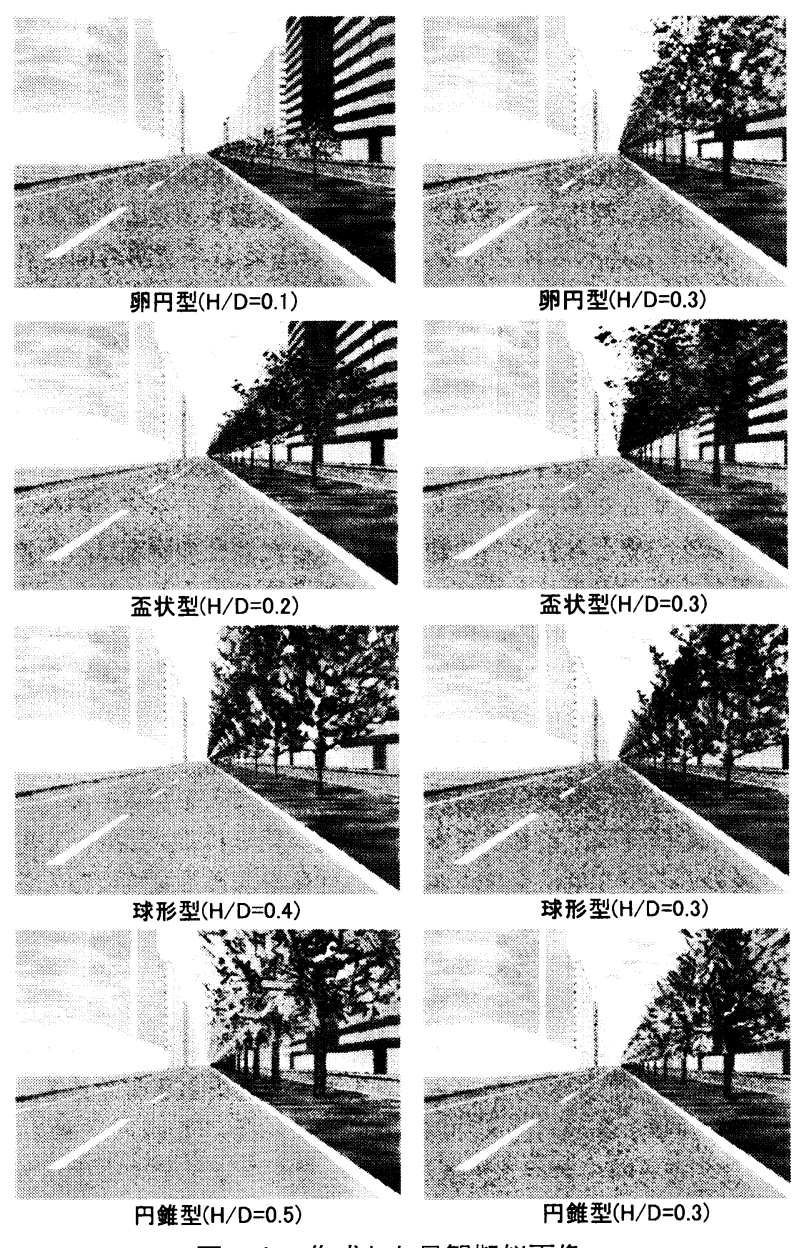

図-1 作成した景観擬似画像

表 -3 景観擬似画像の作成条件

\begin{tabular}{|c|c|c|c|c|c|c|c|c|c|c|c|c|c|c|c|c|c|c|c|c|}
\hline \multirow{3}{*}{$\begin{array}{c}\text { 樹 形 } \\
\text { 採用樹種 }\end{array}$} & \multirow{2}{*}{\multicolumn{5}{|c|}{$\begin{array}{l}\text { 球 形 型 } \\
\text { ハクモクレン }\end{array}$}} & \multirow{2}{*}{\multicolumn{5}{|c|}{$\begin{array}{c}\text { 盃 状 型 } \\
\text { ミズキ }\end{array}$}} & \multirow{2}{*}{\multicolumn{5}{|c|}{$\begin{array}{l}\text { 円 錐 型 } \\
\text { メタセコイア }\end{array}$}} & \multicolumn{5}{|c|}{ 卵 円 型 } \\
\hline & & & & & & & & & & & & & & & & & arnis & Tree & 漆樹 & \\
\hline & K1 & K2 & K3 & K4 & K5 & S1 & S2 & S3 & S4 & S5 & E1 & E2 & E3 & E4 & E5 & $\mathrm{T} 1$ & $\mathrm{~T} 2$ & T3 & T4 & T5 \\
\hline 樹 高(m) & 3.0 & 6.0 & 9.0 & 12.0 & 15.0 & 3.0 & 6.0 & 9.0 & 12.0 & 15.0 & 3.0 & 6.0 & 9.0 & 12.0 & 15.0 & 3.0 & 6.0 & 9.0 & 12.0 & 15.0 \\
\hline 樹高幅員比 & 0.1 & 0.2 & 0.3 & 0.4 & 0.5 & 0.1 & 0.2 & 0.3 & 0.4 & 0.5 & 0.1 & 0.2 & 0.3 & 0.4 & 0.5 & 0.1 & 0.2 & 0.3 & 0.4 & 0.5 \\
\hline
\end{tabular}


表一 4 因子負荷量及び累積寄与率

\begin{tabular}{|c|c|c|}
\hline 評価項目 (形容詞対) & 第一因子 & 第二因子 \\
\hline Q1 開放感がある一圧迫感がある & 0.987 & 0.115 \\
\hline Q2 洗練されているーいない & 0.448 & 0.860 \\
\hline Q3 調和的な一調和的でない & -0.046 & 0.963 \\
\hline Q4 力強い -弱々しい & -0.935 & 0.278 \\
\hline Q5 さわやかなーうっとうしい & 0.857 & 0.399 \\
\hline Q6 緑が豊かな一緑が乏しい & -0.912 & 0.363 \\
\hline Q7 すっきりしたーごみごみした & 0.962 & 0.174 \\
\hline Q8 親しみのあるーない & 0.222 & 0.935 \\
\hline Q9 広々としたー狭苦しい & 0.991 & 0.092 \\
\hline Q10 奥行きのあるーない & 0.872 & 0.309 \\
\hline Q11 軽快な一重苔しい & 0.973 & 0.202 \\
\hline Q12 魅力的な一つまらない & -0.151 & 0.912 \\
\hline Q13 潤いのある一ない & -0.524 & 0.788 \\
\hline Q14 印象的な一印象の薄い & -0.564 & 0.322 \\
\hline Q15 快適な一不快な & 0.474 & 0.841 \\
\hline 固 有 值 & 8.122 & 5.360 \\
\hline 寄与率（\%） & 54.150 & 35.730 \\
\hline 累積寄与率 (\%) & 54.150 & 89.880 \\
\hline
\end{tabular}

〜嫌い〜大変嫌い\} の 5 段階評価で選択記入を求めた。

\section{(2) 分析方法}

まず, 街路景観のイメージを解明するために, 因子分析（主因 子法, バリマックス回転）を試みる。そして, 因子分析で得られ た因子得点を説明変数とし, 評価項目の最後にある「総合的に好 き一総合的に嫌い」という形容詞対を総合評価項目とみなし，こ れを被説明变数とした重回帰分析によって景観評価の要因分析を 行う。最後に, 重回帰分析で得られた総合評価点之樹高幅員比の 関係を分析することにより, 望ましい樹高幅員比の值を樹形ごと に考察する。

\section{（3）因子分析結果と考察}

はじめに, 評定尺度法のデータを用いて因子分析を行ったとこ ろ, 表一 4 に示すように 2 つの因子（固有值 1.0 以上）が抽出さ れ，第一因子に寄与している形容詞対は [広々とした一狭苦しい] [開放感がある一圧迫感がある] をはじめ, [軽快な一重苦しい] [すっきりした一ごみごみした］などで，これらは街路景観の 「開放感」の因子であると解釈できる。一方, 第二因子は, [調和 的な一調和的でない］[親しみのある一ない］[魅力的 なーつまらない［洗練されている一いない］などの 形容詞対が寄与していることから街路景観の「好まし さ」の因子と名付けた。これらのことから, 分離帯高 木植栽について被験者は, 寄与乘の大きさから判断し て,「開放感」と「好ましさ」感の両面から景観イメ一 ジを形成していると考えられる。

次に, 各因子について因子得点を算出して, 各景観 画像について 2 次元座標平面に表したのが黍-2 であ る。なお，図中の $(S 1 \sim K 5)$ の各記号は表一 3 に示し た各景観画像名を指す。この図から被験者の景観イメ一 ジの差異傾向や評価の特性を分析したところ, 以下の ことが明らかとなった。

（i）全体的な傾向として，4樹形のいずれる $\mathrm{H} / \mathrm{D}=0.1$ の画像には「開放感」を感じているが, 「好ましさ」は感じないという評価を与えている。と ころが, $\mathrm{H} / \mathrm{D}=0.2$ の画像になると 4 樹形とも「開 放感」を感じながら「好ましさ」感が上昇し, 特に盃 状型の「好ましさ」感は 5 段階の $\mathrm{H} / \mathrm{D}$ の中で最高 值に達している。円錐型は $\mathrm{H} / \mathrm{D}=0.3$ で「好ましさ」
感が最高值になり, $\mathrm{H} / \mathrm{D}=0.4,0.5$ と樹高幅員比が大きくなる につれ，「好ましさ」感は低下しながら「開放感」は低下してい る。卵円型は, $\mathrm{H} / \mathrm{D}=0.2$ と 0.3 で「好ましさ」感が最高值を 示すが, $\mathrm{H} / \mathrm{D}=0.4 \rightarrow 0.5$ と上昇するにつれて「好ましさ」感は 減少しつつ, 圧迫感が増大する傾向を示した。球形型は, $\mathrm{H} / \mathrm{D}=0.3$ で「好ましさ」感が最高值を示すが, $\mathrm{H} / \mathrm{D}$ が $0.4,0.5$ と増加しても「好ましさ」感は依然としてプラス側に留 まっているのが特徴的である。

これらを樹形別に整理すると，「好ましさ」を感じる樹高幅員 比は, 盃状型で 0.2 と 0.3 のケースであり, 円錐型で $0.2 \sim 0.4$ の 3 ケース, 卵冈型で 0.2 と 0.3 の 2 ケース, 球形型で $0.2 \sim 0.5$ の 4 ケースである。つまり，4 樹形とも $\mathrm{H} / \mathrm{D}=0.2$ と 0.3 では 「好ましさ」を感じており，とりわけ円錐型と球形型は，H／D= 0.4，したがって樹高 $\mathrm{H}=12 \mathrm{~m}$ でも“好ましい”之評価している ことが判明した。

（ii）景観イメージとして「圧迫感」を感じる樹高幅員比は，盃 状型で $\mathrm{H} / \mathrm{D}=0.3,0.4,0.5$ の 3 ケース, 円錐型で $\mathrm{H} / \mathrm{D}=$ $0.4,0.5$ の 2 ケース, 卵円型で $\mathrm{H} / \mathrm{D}=0.3,0.4,0.5$ の 3 ケース,

球形型で $\mathrm{H} / \mathrm{D}=0.3,0.4,0.5$ の 3 ケースである。つまり, 円錐型 を除き，「圧迫感」を感じ始める樹高幅員比は， 0.3 以上であるこ とが分かる。

\section{(4) 景観評価の要因分析}

本研究のように, 景観画像の構成要素が道路と街路樹と建築物 という限定されたシーンでは評価項目間の相関が非常に高くなる ことから，ここでは，総合評価項目 $(\mathrm{y})$ を被説明変数とし，第一 因子 $\left(X_{1}\right)$ と第二因子 $\left(X_{2}\right)$ の因子得点を説明变数とした重回帰 分析を試みた。その結果,

$$
\mathrm{y}=2.885-0.093 \mathrm{X}_{1}+0.409 \mathrm{X}_{2}
$$

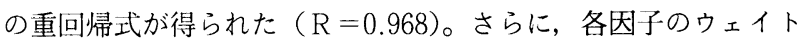
を求めるために標準偏回帰係数 (bi') )算出したところ, 第二因 子である「好ましさ」の $\mathrm{b}_{1}^{\prime}=0.944$, 第一因子の「開放感」の $\mathrm{b}_{2}{ }^{\prime}=0.217$ となり,「好ましさ」の方が「開放感」に比べ, 4 倍以上のウェイトを持つことが判明した。すなわち, 被験者は, 画像に調和感，快適性，親近感等を主体とする「好ましさ」を感 じることにより，その心理が総合評価に結びっくという評価構造 が推測され，総合評価には「好ましさ」感が強い影響を与えるこ とが明らかとなった。

（5）総合評価点と樹高幅員比との関係

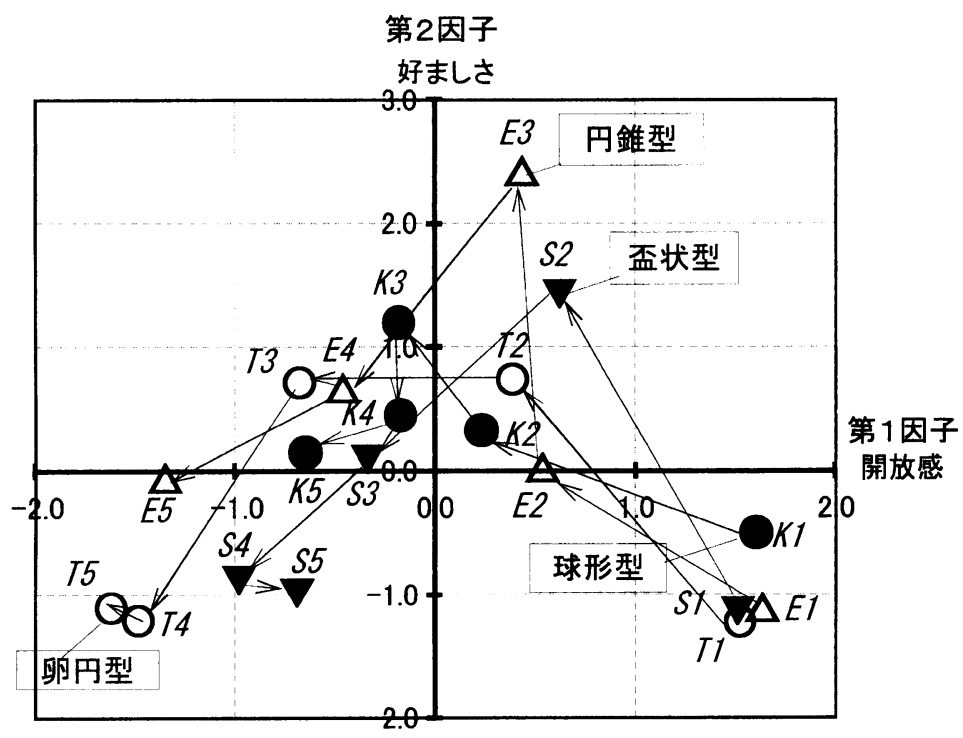

図ー2 各画像に対する景観イメージ 


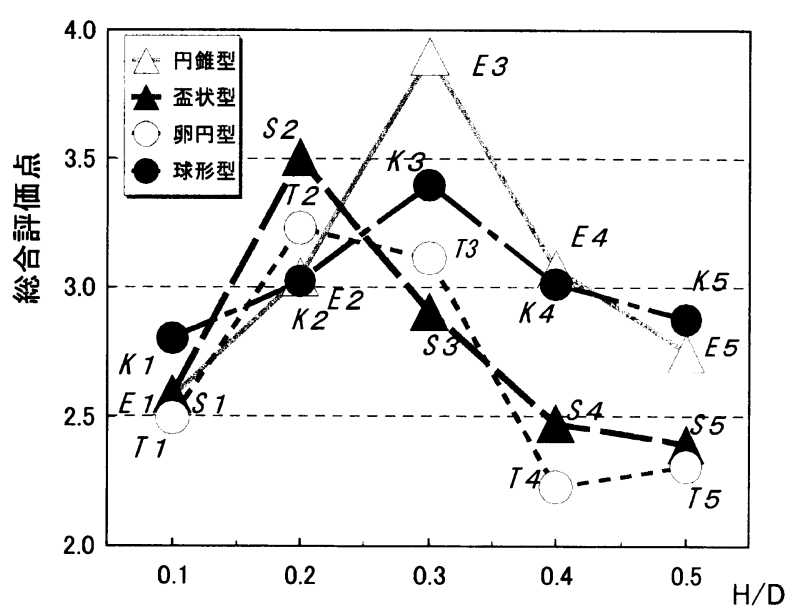

図-3 総合評価点と樹高幅員比の関係

前項において得られた重回州式により, 総合評価は 2 つの因子 でほぼ完全に説明できることが示されたので, ここでは, 重回州 式を用いた推計值を「総合評価点」として算出した。樹高幅員比 毎に各画像の総合評価点をプロットしたのが図ー 3 である。総合 評価点の高い順に, E3， S2，K3，T2，T3，という画像が続き， 上位は $\mathrm{H} / \mathrm{D}=0.2$ と 0.3 で占められた。また, $\mathrm{H} / \mathrm{D}=0.1$ と 0.4 の画像には概ね低い評価点が与えられていることから判断す ると, 被験者は分離帯高木植栽では $6 \mathrm{~m} \sim 9 \mathrm{~m}$ の樹高を望んでい ると思われる。

樹高幅員比別では, $\mathrm{H} / \mathrm{D}=0.1$ と 0.5 はすべての樹形で平均 值 3.0 以下の評価であるが, $\mathrm{H} / \mathrm{D}=0.2$ になると, 4 樹形とも 平均値以上の評価となった。同様に, $\mathrm{H} / \mathrm{D}=0.3$ では盃状型を 除き平均值以上であるが, $\mathrm{H} / \mathrm{D}=0.4$ になると, 盃状型と卵円 型の評価が急降下していることが分かる。

一方, 樹形別では円錐型が $\mathrm{H} / \mathrm{D}=0.3$ で高評価を得ているの が特徴的であり, 全 20 画像の中で最上位に評価されている。盃 状型はかなり特徵的な変化を示しており, $\mathrm{H} / \mathrm{D}=0.2$ の画像は 全体でも 2 番目の高評価を示したが, それ以外の樹高幅員比では 低い評価が与えられた。特に, $\mathrm{H} / \mathrm{D}=0.4$ と 0.5 の画像では, 図一 2 でも分かるように,「開放感」の低下,すなわち圧迫感が増
大することにより, 総合評価が低減したと思われる。球形型は, $\mathrm{H} / \mathrm{D}=0.3$ の画像で高く評価されたが, それ以外の樹高幅員 比では, 低評価ながらも変動は他の樹形に比べ最も小さいと言え よう。卵冈型は, $\mathrm{H} / \mathrm{D}=0.2$ と 0.3 の画像で平均值以上の評価 点であるが, $\mathrm{H} / \mathrm{D}=0.4$ と 0.5 の画像では 4 樹形の中で最も 低い評価が与えられた。これも図一2 から明らかなように，被験 者は,樹高が 12〜 $15 \mathrm{~m}$ になると圧迫感を感じるのがその理由と考 えられる。

\section{5. おわりに}

今回の景観画像は, 沿道建築物の配置や配色，あるいは樹木の 枝下高や形状のリアリティなどの点で改良の余地があり，また， 静止画像を用いての評価であること等，必ずしも現実の街路景観 を反映した画像になっていないことから，本研究で得られた知見 の応用可能性に関しては自ずと限界がある。そこで, これらの限 界を認識した上で，本研究から得られた主要な結果を以下に示す。

1) 街路景観の評価は，「好ましさ」と「開放感」の 2 つの評価 軸によって表される。さらに, 総合評価には「開放感」よりも, 快適性や親近感, 調和感を中心とした「好ましさ」の方が強く （ウェイトは1：4 程度）影響を及ぼしている。

2 ) 望ましい樹高幅員比は, 円錐型と球形型では 0.3 (実際の 樹高で $9.0 \mathrm{~m}$ ), 盃状型では 0.2 (同 $6.0 \mathrm{~m}$ ), 卵网型は $0.2 \sim 0.3$ (同 $6.0 \sim 9.0 \mathrm{~m}$ ) で，それぞれ高評価が得られることが判明した。 つまり，分離帯高木植栽時の景観上の望ましい樹高は，総幅員の 2 割〜 3 割程度の值であることが示されたと言えよう。

このように，樹高幅員比は，所与の樹形に応じて景観面からの 望ましい樹高の目安を与える手がかりになるのではないかと考え ている。なお，今後は，CGアニメーションの採用等，よりリア リティを高めた画像を用いて，景観評価に及ぼす(1)建物高さや色 彩，(2)枝下高の高低，(3)高木の植栽形式（間隔・枝張り等)，(4) 樹木の種類（常緑樹・落葉樹）の各影響を分析するなど，検証す べき課題が多く残っている。このように解明すべき多くの検討課 題を残してはいるが, 本研究が今後の分離帯高木植栽導入への. 助となれば幸いである。

終わりになりましたが, 本研究を遂行するに当たり, 大分大学 工学部建設工学科の佐藤誠治教授から数々の有益なご助言とご指 導を賜りました。ここに記してお礼申し上げます。

\section{参考文献}

1）日本道路協会編（1988）：道路緑化技 術基準・同解説：丸善

2 ) 下村泰彦・増田昇他（1992）：フォト モンタージュ法による街路修景・緑化 モデルに関する研究：造園雑誌 55(5), 289-294

3 ) 市橋秀樹・渡部力・小島桃子 (2000): 街路植栽が歩行者および運転者心理に 及ぼす影響：ランドスケープ研究
63(5), 795-798

$4 ）$ 山滝佳子・佐藤誠治他（1999）：CG を用いた街路プロポーションに関する 研究一建物と街路樹高さの関係一：日 本建築学会第 22 回情報システム利用 技術シンポジウム論文集，25-30

5 ) 亀野辰三・八田凖一(1997): 街路樹・ みんなでつくるまちの顔：公職研, $32-39$

6 ）渡辺達三（2000）：「街路樹」デザイ

\section{ン新時代, 84-92, 裳華房}

7 ）龟野辰三・八田凖一（1995）：わが国 における都市を代表する街路に関する 研究: 第 21 回日本道路会議論文集, 92-93

8 ）亀野辰三・八田凖一（1998）：「樹高 幅員比、に基づく景観イメージの評価： ランドスケープ研究 61(5)，617-620

Summary : This study refers to the landscape evaluation of planting high trees in separators from drivers' point of view. First of all, the wide-width streets in front of stations were simulated using computer graphics. Then, landscape evaluation models were made with different tree shapes and tree-height to street-width ratios. After that, landscape evaluation experiments were performed and the methodology of testees' evaluation were analyzed using factor analysis and multiple regression analysis. The following results were obtained: 1) Assessment of streetscape can be expressed by using 'desirability feeling' and 'feeling of opening'. 2) The desirable tree-height to street-width ratio (H/D) was found to be $0.3(9.0 \mathrm{~m}$ in real tree height) in cone-shaped and spherical shape trees, $0.2(6.0 \mathrm{~m}$ in real tree height) in sake-cup shaped trees and $0.2 \sim 0.3(6.0 \sim 9.0 \mathrm{~m}$ in tree height) in oval shape trees respectively. It has become clear that high assessment values can be obtained when the above ratios are applied. In short, as far as landscape is concerned, the desirable height of the trees in separators is thought to be approximately $20 \sim 30 \%$ of the total width of the street. 